\title{
FEKETE CSABA
}

\section{A Szákiak}

Régóta halasztott munkába fogtam 2015 nyarán. Kutatatlan 17. századi kéziratos ágenda vizsgálatába és esetlegesen szövegének kiadásra való előkészítésébe. Eközben botlottam bele a Komárom megyei prédikátor család kevert és hiányos adataiba. Elözetesnek szánt írásomat reménységgel bocsátom közre, hátha a korszak avatott kutatói pótlásokra bukkanva kiegészítik, pontosítják és jelentősen árnyalják a mostanra kialakult ideiglenes képet.

\section{Müködött-e Szencen Száki István nevü prédikátor?}

Szabó Károly azt közölte Száki Ferenc (1635/1636-1694 u. $)^{1}$ utrechti disputájának bibliográfiai leírásában, hogy 1656-ban „Ajánlja a szerző az I. részt atyjának Száki István szenczi papnak...”. Herepei Jánosnál is fölbukkan a Szenczi Száki István név (alább látjuk). Ne intézzük el kézlegyintéssel, hogy ez nyomdahiba vagy elírta a feldolgozó. Szívósan tovább élő áladatok keletkezhetnek az apró elírásokból és adathiányokból.

Székelyudvarhelyen található egyetlen példánya az imént idézett disputának. Miként írja atyja nevét a tisztelgő fiú? Ö a helyes keresztnevet igazán tudhatja.

„Reverendo, Clarissimo, Doctissimoque Viro, Johanni Szaki Pastor ovium Jesu Christi in Ecclesia Orthodoxa Szenciensi fidelissimo, [ nec non $]^{3}$ Ecclesiarum Reformatarum in superiori Pannonia, cis et ultra Danubium passim dissitarum Superinintendenti vigilantissimo, Domino et Parenti suo filiali semper observantia et reverentia colendo." ${ }^{4}$

${ }^{1}$ Hiányos életrajza és korábban ismert műveinek jegyzéke: ZovÁNYI Jenő, Magyarországi protestáns egyháztörténeti lexikon, 3. jav. bőv. kiad., szerk. Ladányi Sándor, Budapest, Kiad. a Magyarországi Református Egyház Zsinati Irodájának Sajtóosztálya, 1977, 566. - Újszáki névváltozatot is közöl, erre alább vissza kell térnünk.

2 RMK III. 1971.

${ }^{3}$ Száki Ferenc alkalmaz [ ] zárójelet.

${ }^{4}$ Megköszönöm Róth András Lajos kollegiális szívességét, aki azonnal megnézte és megküldte az unikális példány adatait. - A címlapon látható az egykori ovális tulajdonbélyegző Székelyudvarhelyi Ev. Ref. Kollégium Közkönyvtára felirattal. A mai tulajdonos a Református Kollégium 
A keresztnév helyességében azért sincs miért kételkednünk, mert az ajánlott közismertségét több nyomtatott ajánlás tükrözi. Kászonyi Herceg János (1630 k.1663 u. $)^{5}$ 1657-ben egész sor ajánlott neve után szintén helyesen írta a Szencen prédikátor és püspök tisztséget betöltő pártolója nevét a címlap verzójának alsó harmadán:

„Nec non Admodum Reverendum, doctrinam et pietate eximiis, D. Johanni Száki, D. Stephano Kaposi, D. Georgio Hosdati, Illi in Ecclesia Szencciensi Pastori dignissimo, nec non Superanttendenti ${ }^{6}$ Ecclesiarum reformatarum pannoniae superioris exquisitissimo..."

Csúzi Cseh Jakab (1639-1695) - még Komáromban rektorként, később elüzött prédikátor és gályarab, élete végén püspök -, 1660-ban Patakon megjelent metafizikai disputájának ajánlottai között szintén olvassuk Joh. Szaki nevét.7 Kapcsolatuk tartós lehetett. Már samarjai lelkészként, 1668-ban Hasznosabb mesterség nincsen ez világon kezdetü verssel Száki Ferenc is köszöntötte Csúzi Cseh Jakab Kincses tár-ház címü könyvét. Versének aláírása:

\section{„Joh. Szaki, past. Samariens. et superintend."}

Korábban, 1632-ben, Séllyei Halász (Piscatoris) Ferenc (1596 k.-1648) szintén ajánlotta franekeri értekezését többek között az akkor még prédikátori pályája elején járó és akkor már Csütörtökön szolgáló prédikátornak. ${ }^{9}$ Nevét így írja, eltérően az előbbiektől:

\section{„Johanni Sz. Szencino”.}

Kettős keresztnév nem bukkant föl eddig, így aligha remélhetjük, hogy még ismeretlen adat igazolná a tévesztést. A változatok arra is figyelmeztetnek, hogy esetleg a Szenci nevüek között is találhatunk még adalékot, akiket a Száki családnév elhagyásával jegyeztek. Másrészt ígéretes a többi ajánlott nevéből adódó kapcsolatrendszer. A fejtegetés sok fáradozással jár. Egyszerübb kézikönyvekhez nyúlni.

1772-ben alapított gyüjteményének örököse, a Haáz Rezső Múzeum Tudományos Könyvtára. www. sulinet.huloroksegtarldata\Haaz_Rezsolindex.htm

${ }^{5}$ RMK III. 1982; megköszönöm Tanászi Árpádnak a sárospataki példány adatainak ellenörzését, amelyet magam csak korábban láthattam.

${ }^{6}$ Kizárólag a superattendens szóalakot használta Beythe István a két protestáns felekezet utolsó közös püspöke.

${ }^{7}$ RMNy 2933.

${ }^{8}$ RMNy 3478.

9 RMK III. 1477; Bányai Rékának köszönöm, hogy a névalakot ellenőrizte a Teleki Téka (Marosvásárhely) példányán. 
A baj nem jár magában. Szinnyei vegyítette a csallóközi (felső-dunamelléki) püspök adatait Ferenc fiáéval. ${ }^{10}$ Nem ismerte sem idősb sem ifjabb Szenci Száki János nevét, Ferenc fiáról meg tévesen közölte, hogy „,bölcseleti doktor, ref. superintendens", noha addigra már tisztázta az idősb és ifjabb Száki János életének addig ismert fontosabb adatait Földváry László. ${ }^{11}$ Teológiai doktor volt Száki Ferenc, és nem volt superintendens (egyéb adataira később visszatérek). Az RMSz ${ }^{12}$ tovább élteti az elvétéseket, Szinnyeire hivatkozva. Száki (Sakius, Szenci Száki, Újszáki) Ferenc nevénél még hozzáadja: „,Száki János id. és ifj. adatai is”, ${ }^{13}$ azaz együtt megjelentek Szinnyeinél. Az ifjabb Száki Jánoshoz tartozónak vélt adatokból eredhettek az alább szóvá tett attribúciók.

Azért sem bizonyos, hogy közönséges elírás az István név, mert a vétség talányát fokozta Hellebrandt Árpád. Száki Új István szerzőt is megnevezett az RMK III. mutatójában, akinek eszerint a nevét ajánlottként így kellene olvasnunk két nyomtatott disputában, azaz Kászonyi Herceg Jánoséban és Körmendi Péterében. ${ }^{14} \mathrm{Az}$ elöbbiről már láttuk, nem így van. A második alább következik, több szempontból bizonytalan, mert többek között más személyről lehet szó.

Innen is eredhetett talán az RMSz mutatójában az Újszáki Ferenc név. Csakhogy ez Zoványi lexikonában is fölbukkan. Nehéz volna magyaráznunk. Száki és Sakius olvasható az ismert példányokban, külföldön, egyetemi beiratkozáskor a matrikulákban is. ${ }^{15}$ Pedig valóban nem ritkán történt, hogy sok szerző különböző hol így, hol amúgy írta a saját háromelemü nevét, vagy pedig teljes alakban soha nem is használta. Alább még megkísérlem a koholtnak vélhető névalak tisztázását.

A föntebbiek után hadd következzék itt Száki János életrajzi vázlata, mert ezt - erre már utaltam - Zoványi sem ismeri. ${ }^{16}$ Nem közölt róla cikket sem a Pallas, Révai, Életrajzi lexikonunk vagy újabban az ÚMIL sem.

${ }^{10}$ Magyar irók élete és munkái, a Magyar Tudományos Akadémia megbizásából írta Szinnyei József... Budapest, Kiadja Hornyánszky Viktor, 1909, XIII. 301-302.

${ }^{11}$ FöLdVÁRY László, Száki János ekeli prédikátor háromszoros megkínzatása és megégettetése Komáromban = Protestáns Szemle, 15(1903), 442-453. Egy ábrával. Később közlése adatait felhasználta az egyházkerület történetének megírásakor.

12 VIX Györgyné, Régi magyarországi szerzők (RMSz), I. A kezdetektől 1710-ig, szerk. és befejezte: P. Vásárhelyi Judit, Budapest, Országos Széchényi Könyvtár, 2008, 764 (Bibliotheca Nationalis Hungariae).

13 RMSz 764.

14 RMK III. 1982 és 2206.

15 Keresztnevét kivétel nélkül Franciscusnak írta, családnevét pedig Száki (Franeker), P. Szakj (Utrecht), Szaki (Harderwijk), Szaki és Sakius Samaria (Leiden) változatokban. Vö. BozzAY Réka, LADÁNYI Sándor, Magyarországi diákok holland egyetemeken 1595-1918, Hongaarse studenten aan Nederlandse Universiteiten 1595-1918, Budapest, Közreadja Az Eötvös Loránd Tudományegyetem Levéltára, 2007, 370, 1334, 2403, 2797. (Magyarországi diákok egyetemjárása az újkorban, 15).

${ }^{16}$ Korábban Földváry László hivatkozott tanulmánya nyomán írta meg az ifjabb Száki János hiányos életrajzát; ebben csupán az a figyelmeztetés olvasható, hogy „Nem tévesztendő össze hasonlónevü atyjával, ki 1656-1675. püspöke volt a samarjai egyházkerületnek”. Zoványi Jenő cikkei 


\section{Superattendens Ecclesiarum reformatarum Pannoniae superioris}

Tudomásunk szerint a legidősebb Szenci Száki János prédikátor volt sorban a következő helyeken: Csütörtök mezőváros (1632-ben már biztosan, és még 1640es években is), Szap (164?-1654), Szenc (1654-1665), Neszmély (1665-1668), Somorja (1668-1672); innen elüzték, ezért Tatára ment (1673-1674). Somorján már esperes volt (1654-1656), majd pedig felsődunamelléki (csallóközi, somorjai) püspök (1656-1675). Tatáról idézték a pozsonyi törvényszék elé (Delegatum Judicium), és elítélték. Neszmélyen halt meg talán; habár feltételesen Velencét szokták írni. Ezt cáfolta a gályarabok levelezése alapján Földváry László, azzal hogy nem bujdosott külföldre. Tudniillik a püspök halálának hírét Séllyei M. István (1627-1692) írta meg Velencébe. Ebből keletkezhetett a téves adat. ${ }^{17}$ Még nem történt meg tehát halála körülményeinek és helyének a végleges tisztázása.

Püspökké a Farkasdon tartott zsinat választotta Száki Jánost 1656-ban, ezzel van összhangban fia disputájának föntebb idézett ajánlása. ${ }^{18}$

Idősb Szenci Száki János születését 1600-1610 közé tehetjük. Ezt fiai részben ismert életrajzi adataiból következtetem. Tudjuk Ferenc fiának a külföldi beiratkozásából, hogy ő 1635-ben vagy 1636-ban született. Idősebbnek gondolhatjuk János fiát, az ekeli esperest. Apjuk, az idősb János nagyjából huszonöt évesen már családos és gyermekes prédikátor lehetett a kor általános szokása és elvárása szerint, már 1632-re. Séllyei Halász Ferenc nyomtatásban megjelent ajánlásából az is következik, hogy felsőbb tanulmányait legkésőbb 1625-ben elkezdte, így az 1630-as évek elején már meghívható és beiktatott prédikátor lehetett.

Térjünk még vissza az első ajánláshoz. Milyen címmel illette atyját disputájában Szenci Száki Ferenc? Clarissimus ac Doctissimus. Tudvalevő, hogy ez a rang járt akadémikusoknak, külföldön peregrináló tiszteletes és tudós prédikátoroknak. Jelenleg azonban semmit nem tudunk arról, hogy idősb Száki János bárhol külföldön tanult volna. Hazai iskolázásáról sincsenek adataink. Családi kapcsolatáról is csak az ajánlások árulkodnak.

Szencen, Szenci Molnár Albert szülővárosában tehát nem volt Száki István nevü prédikátor 1656-ban. A hibás keresztnév is, és a nemlétező Száki István nevü szerző is törlendő a régi magyar könyvtári mutatókból. De ezzel nem intéztünk el mindent.

a „Theologiai Lexikon” részére a magyarországi protestantizmus történetéböl, kézirat gyanánt, Budapest, 1940, 427.

17 A Dunántúli Református Egyházkerület prédikátorai és rektorai I. 1526-1760, Pápai Református Gyüjtemények, Pápa, 2009, 604 (A Pápai Református Gyűjtemények kiadványai, Szerk. Köblös József, Kránitz Zsolt, Forrásközlések, 10) Halálhíréhez 1. még: Sárospataki Füzetek 1863, 61.

${ }^{18}$ Vázolja püspökségét is többek között ThuRY Etele, A Dunántúli Református Egyházkerület története, I-II, (1523-1674), (1670-1734), Pozsony, Kalligram Könyvkiadó, II, 242 (Csallóközi Kiskönyvtár). 


\section{Ifjabb Szenci Száki János szerezte-e apja versét?}

Elkülöníti apjától az azonos nevü fiút a RMSz, de esetlegesen azt is feltételezi, hogy az akkor már egy évtizede püspök atya két ismert köszöntő versét (vagy legalább az egyiket?), amelyet 1981-ben ismét közreadott a Régi Magyar Költők Tára, ${ }^{19}$ nem ő szerezte, hanem a fia. Ez következik abból, hogy a Szinnyeinél található adatok állítólag mindkettőjükre vonatkoznak. Ezért mindkettőjük nevénél utal a versek kritikai kiadásának ugyanazon helyére. ${ }^{20}$ Tekinthetjük-e a szerzőséget bizonytalannak vagy eldönthetetlennek az RMKT 10. kötete óta is? A Titkait Istennek sáfárló szolgája kezdetủ vers szerzőjének neve a 76. szám jegyzetében „, Szenczi Szaki Janos, Superintendens és Samarjai prédikátor, Eklén 6. Maji 1666". ${ }^{21}$ Ugyanott olvassuk azt is, hogy a vers szerzője nem az ifjabb Száki János. De a másik versé sem. Mert annak szerzője is megvan a 77. szám jegyzetében: „, Johannes Saki Pastor Samariensi Superintendens”. Kétségtelen tehát, hogy ezeket a szuperintendens apa szerezte, és nem fia, Ekel prédikátora és komjáti esperes. ${ }^{22}$ Ezt a hibás feltételezést törölnünk kell.

\section{Lehetett-e Komáromi Csipkés György müvének szerzője ifjabb Száki János?}

Ezt szintén lehetőnek véli ifjabb Száki Jánosról az RMSz, ugyanazon feltételezés következményeként, kimondván, hogy az „RMK. I. 1042 szerzője esetleg ő.” Azzal együtt teszi ezt, hogy apja neve után sem hiányzik ugyanerre az RMK számra való hivatkozás. Valóban írt álnéven is a debreceni professzor és prédikátor. Ez vegyült volna valamiképpen az adatokhoz? Ebből is jogosulatlan volna arra következtetnünk, hogy a Szenci Kertész Ábrahám által Szebenben nyomtatott kiadvány címlapján, Az igaz hit címü párját rikító teológiai munkán, amely egyik legvelösebb szerzeménye, esetleg álnév a Comaromi Csipkes György (1628-1678) név.

Visszaköszön itt egy másik tévesztés is, említettem föntebb. Az igaz hit egyik legyeződíszes kötésben megmaradt példányával kapcsolatban írja Herepei János Szenczi Száki Istvánnak a köszöntő vers szerzőjét. ${ }^{23}$ Ezt a nyomtatott kötetből így nem írhatta ki, talán készpénznek vett valamilyen hivatkozást.

Versszerzőnek nem mondhatjuk ugyan, de érdemes felidéznünk néhány mozzanatot ifjabb Száki Jánosról. Teljesebb életrajzát eddig nem sikerült senkinek összeállítania.

${ }_{19}$ Régi Magyar Költő Tára, XVII. század, 10. kötet, az 1660-as évek költészete (1661-1671), Sajtó alá rendezte Varga Imre, Budapest, Akadémiai Kiadó, 1981, 76. és 77. szám.

${ }^{20}$ RMKT XVII/10. 716.

21 RMNy 3322.

22 ZovÁNYI 1977, i. m. 334. Tévesen írják néhol a komáromi egyházmegye esperesének; ott Csúzi Cseh Jakab volt az esperes, akit szintén elüztek 1672-ben.

${ }^{23}$ Adattár XVII. századi szellemi mozgalmaink történetéhez, II., Apáczai és kortársai, Herepei János cikkei, Szerk. Keserü Bálint, Budapest-Szeged, 1966, 171. 


\section{Flammis Comarini consumptum}

Legpontosabban halála idejét és módját ismerjük. Több napos kínzás után Komáromban égették meg 1672. szeptember elsején. Néhány év múlva először a gályarab Kocsi Csergő Bálint (1600-1666) írta meg az eseményt 1676-ban. Munkája sokáig csak kéziratban terjedt. ${ }^{24}$ Majd másik gályarab, azaz Otrokócsi Fóris Ferenc (1648-1718) tárgyalta a vallásügyi sérelmeket, és a soproni országgyülést, ő is taglalta Száki János megégetését. ${ }^{25}$ Tőle vettem e bekezdés címét. Korabeli kéziratos és nyomtatott források nyomán tudósított a kegyetlen eseményről Debreceni Ember Pál (1660-1710) is. ${ }^{26}$ Mindezek nyomán említette azóta számos hazai és külföldi munka, szinte mindig további kutatás vagy az adatok ellenőrzése nélkül. Az üldöztetés és a megmaradás eseményeinek megörökítése arra is választ ad, hogy a vértanú Száki János életéről másodlagosnak tekinthettek minden egyéb adatot. Vagy ha megörökítették is, elpusztult, feledésbe merült. Kezdve azzal, hogy elüldözött atyjával együtt kik gyászolták. Nem tudjuk, hol tanult ifjabb Száki János. Külföldön tanulásáról nincs adatunk. Nem tévedhetünk nagyot, ha halála idején negyvenes éveiben járónak képzeljük, azaz 1630 körül (inkább korábban) születhetett. Az is bizonyosnak vehető, hogy családos volt. Tudjuk róla, hogy hol volt esperes, de azt nem, hogy volt-e korábban máshol is prédikátori tisztsége.

\section{Ki volt Újszáki Ferenc?}

Teljesen légből kapott név mégsem lehet a föntebb megemlített Száki Új István, és szintén lehet további hibás azonosítások eredője.

A Száki Ferenccel egyidős Körmendi B. Péter (1635/1636-1691), később tiszántúli püspök, aki Leidenben tanult 1663-ban, disputáját több városabeli (azaz szatmári) lelkésznek ajánlotta, majd pedig felsorolt Németalföldön peregrináló társainak. Közbül, mintegy a két névjegyzék ellenpontjaként következik még a minket most érdeklő prédikátor neve is. Nem magában, az ajánlottak között van még Kaposi Geszti Pál (1635 k.-1673 u.), Érsekújvári Karai Orbán (1630 k.-1690), Szendi Dávid (?-?) és Porcsalmi András (1617-1681). Ezek társaságában találjuk a jelenleg még azonosítatlan prédikátor nevét:

\section{„Dominus Stephanus Uy-Saki.”}

${ }^{24}$ Vö. Bod Péter fordításának (1738) új kiadásában, Galéria omnium sanctorum, A magyarországi gályarab prédikátorok emlékezete, Budapest, Magyar Helikon, 1976, 34.

${ }_{25}$ Oтroкócsi Fóris Ferenc, Apocalyptica Tuba Quinta... (Amsterdam, 1690, RMK III. 3604), 63.

${ }_{26}$ Debreceni Ember Pál, Historia ecclesiae reformatae in Hungaria et Transyalvania, edidit Friedrich Adolph Lampe, Trajecti ad Rhenum, 1728. - A magyarországi és erdélyi református egyház története, fordította Botos Péter, Sárospatak, 2009. 
A prédikátorok ellenreformációs üldöztetése általános volt már a 17. század elejétől, ${ }^{27}$ exul prédikátorokkal nem csupán majd az úgynevezett gyász-évtizedben folyamán találkozunk, az ajánlottként soroltakról ezért mondhatja, hogy ők

\section{„Concionatoribus in Hungaria (eheu afflictissimae) facundissimis.”}

Ezek sorában sem Németi, sem Szatmár gyülekezetéből nem tudunk arról, hogy ott Újszáki nevü prédikátor szolgált volna a többiekkel együtt. Zoványi még úgy tudta, hogy „1665 végén még Szatmárnémetiben lelkészkedett” Érsekújvári Karai Orbán, ${ }^{28}$ de az ajánlás szerint ennek már évekkel korábban így kellett történnie, ha Körmendi jól tudta külföldön. Kaposi Geszti Pál is valóban lelkészkedett Szatmárnémetiben 1658-1668 között. Porcsalmi András ellenben ekkor Kolozsvárott tanított. Szendi Dávid pályája ismeretlen, és Újszáki István személyéről sem ismerünk eddig semmiféle biztosat. Ezért nem lehet módunk arra, hogy eldöntsük, esetleg az ország más vidékéről került ide, és esetleg rokonságban volt a Komárom megyei Szákiakkal. Ez még bizonytalanabbnak mutatja azt, hogy az Újszáki családnevet ráruházzuk Száki Ferencre.

\section{Szenci Száki Ferenc és munkássága}

Nagy vonalakban összegezzük a csallóközi püspök fiának az életére és munkásságára irányuló eddigi kutatást.

Elvileg lehetséges volna az Újszáki családnév is, ellenben Szenci Száki Ferencre vonatkoztatva dokumentálatlan, ezért valótlannak kell tekintenünk. Valószínüleg koholmány lehet, a Száki Új családnévből kitalált változat.

Debrecenben és Sárospatakon is beiratkozott 1652-ben, és már három év múlva Utrechtben tünt fel. Majdnem biztos, hogy valahol már tanult előzőleg egy vagy két évig. A legtöbb diákkal ellentétben az ő bujdosása feltünően megnyúlt, tizenkét esztendőre terjedt. Ennek ellenére majd csak harminckét évesen szerzett doktori fokozatot. Járt közben Angliában is, nevelősködött, de mégis kérdéses, mivel teltek évei?

Szabó Károly bibliográfiai kézikönyve óta korábban is tudtunk annyit Szenci Száki Ferencről, hogy háromszor vitatkozott külföldi bujdosása első öt évében. Ezen disputái megjelentek, mindegyikből Székelyudvarhelyen van az egyetlen ismert példány:

De orthodoxa antiquitate et heterodoxa novitate. Pars 1-2. Utrecht, 1656. RMK III. 1971,

De origine transsubstantitationis. Utrecht, 1658. RMK III. 2025,

27 L. például az 1608-1670 közötti módszerekre SzABó Előd, A protestáns tisztségviselök üldözése, Adalék a XVII. századi katolikus restauráció módszereihez = Református Egyház, LXII(2010), 18-20.

28 ZovánYi 1977, i. m. 182. 
De regimine ecclesiae sub Veteri et Novo Testamento. Harderwijk, 1662. RMK III. 2162.

Túlzó mértékűnek ennyi egyáltalán nem tekinthető az 1655-1662 évekre vetítve. Némelyik szorgos diák akár egyetlen évben vállalt ennyit. Nem bizonyos azonban ma már, hogy mindent tudunk külföldi pályafutásáról, teljesítményéről és tevékenységéről. Egyáltalán nem értékmérő a terjedelem, de eme negyedrét munkák összesen harmincnyolc levélre rúgnak. Évekkel későbbi disputája (szintén Székelyudvarhelyen van egyetlen példánya) a következő, ez már magában nagyobb terjedelmü, mint az előzők, hatvannyolc levél:

De conflictu Jesuitico, inter doctrinam Jesu, et Jesuitarum. Leiden, 1666. RMK III. 2346.

Egy ideig mindössze ennyi volt ismeretes róla, ezért a Budai Gergely szerkesztette Theológiai Lexikon számára (amely a háború miatt soha nem készült el) Zoványi csupán azt írhatta 1940-ben, hogy „További sorsa nem ismeretes”. ${ }^{29}$ Nem volt ismeretes Száki Ferencnek a Londonban (mások müveivel együtt) megjelent Zrinyi ódája (1665) sem:

Infelix bellum felicis quondam victoris illustr. Comitis Nic. Zerenyi... Summa belli predicti... London, [1665] RMNy 6492.

Ez már ráirányítja figyelmünket arra, amit Szabó Károly és Szinnyei kora egyáltalán nem ismert még, de még Zoványi sem említhetett; angol kapcsolataira, angliai tartózkodására és nevelősködésére. Például nincs rálátásunk arra, hogyan és miben müködött még együtt a latin nyelviskolát szervező és végleg a szigetországban maradt Jászberényi Pállal (-1669), valamint a hazatért, és Zemplénben prédikátor, majd exul Szendrei Ferenccel (1633-1673 u.). A további feltáráshoz elkészítette az eddig legteljesebb adattárat Gömöri György. ${ }^{30}$

Még ugyanabban az évben, mint előzménye, napvilágot látott aztán Száki Ferencnek az Elsevir nyomdában kilenc disputája, Leiden, 1666 impresszummal. Önálló megjelenésük miatt mind önálló bibliográfiai tétel. Tizenhét részes múé, címük az előzőt ismétli. Ezekből csupán Szentpétervár nemzeti könyvtára őriz példányt. Nyolc levelesek, a legutolsó csak négyleveles, együttes terjedelmük tehát százharminckét levél.

29 ZovÁnYI 1977, i. m. 427.

${ }^{30}$ GöMÖRI György, Magyarországi diákok angol és skót egyetemeken, 1525-1789, Hungarian Students in England and Scotland, 1525-1789, Budapest, 2005 (Magyarországi diákok egyetemjárása az újkorban, 14). Szenci Száki Ferenc: 166. szám, Jászberényi Pál: 28. szám, Szendrei Ferenc: 124. szám. 
De conflictu Jesuitico, inter doctrinam Jesu, et Jesuitarum. ${ }^{31}$

[Pars] prima.

[Pars] tertia.

[Pars] quinta.

[Pars] septima.

[Pars] nona.

[Pars] undecima.

[Pars] decima-tertia.

[Pars] decima quinta.

[Pars] decima septima.
RMNy 6510 (=7690),0

RMNy 6511 (=7692),

RMNy 6512 (=7692),

RMNy 6513 (=7693),

RMNy 6514 (=7694),

RMNy 6515 (=7695),

RMNy 6516 (=7696),

RMNy 6517 (=7697),

RMNy 6518 (=7698).

Zoványi még egy értekezésének címét közölte, ezért kapta doktori fokozatát, ezt Szabó Károly nem ismerte még. Az újabb szakirodalom megerősítette. ${ }^{32}$

De Melchisedeco, Harderwijk, Zutphen, 1667.

1667-ben megszerzett doktori fokozatáig ennyit tudunk külföldi tanulásáról. Valószínűleg nem mindent. Megérdemelné Szenci Száki Ferenc, hogy emlékét legalább kismonográfia szintjén föltárják a közeljövő kutatói. Ígéretes téma feltáratlan hollandiai és angliai kapcsolatrendszere. Jóval szerencsésebb körülmények között élő nyugati protestánsok intézményeiben maradhattak észrevétlenül lappangó adalékok. Igy a kitelepedett Jászberényi Pál és a többször Angliába látogató Körmendi Péter körében. Németországi éveiről (Kassel és Oppenheim) is kiderülhetne legalább annyi, hogy mivel foglalkozott az 1667 utáni évtizedekben, és hazaiak közül kikkel maradt kapcsolatban.

\section{Milyen müvet szerzett idősb Száki János vagy valamelyik fia 1671-ben?}

Végül kérdőjellel feltételezi az RMSz azt is, hogy idősb Szenci Száki János „,vallásos mű szerzője: 1671". A többi hasonló tisztázatlanságból következően is azt kell vélnünk, ameddig újonnan felbukkant adat ellenkezőjét nem igazolja, hogy itt szintén hiányos értesülésből eredő vétség a ludas. Alighanem Zoványi közlése. Önála ugyanis ez van: „Az azonban nem tudható, hogy melyikük írta »A helvét valláson levő ecclesiáknak... ceremoniájokról« (1671)."33 Azaz vagy Száki Ferenc, vagy ifjabb Száki János, sőt akár idősb Száki János munkájának vélt egy ilyen címü munkát. Ugyanakkor figyelmeztetett, mint már 1640-ben, hogy az

${ }^{31}$ Az első RMNy szám a hivatkozás nyomán leírt, a második a példány alapján részletezett leírást jelenti a következő jegyzetben megnevezett kiadványban.

32 RMK Sorszám nélkül közli Régi magyar könyvtár, III-dik kötet... Pótlások, kiegészitések, javítások, 3. füzet, Budapest, Közreadja az Országos Széchényi Könyvtár, 1992, 702, Schutte, O., Het Album promotorum van de Academie te Harderwijk, Zutphen, 1980, nyomán.

33 ZovÁnYi 1977, i. m. 566. 
ifjabb Száki János „,nem tévesztendő össze hasonló nevű atyjával, ki 1656-tól 1675-ig püspöke volt a samarjai egyházkerületnek”. Láttuk, bizony ezt az összetévesztést Szinnyei is elkövette, és a tévedést átvették használói.

Olvasható lesz készülő tanulmányomban a munka elemzése, forrásai, és a jelenleg feltárható egyéb adatok. Ide most annyi tartozik, hogy miért nem lehet a fönt említett három Száki közül egyik sem a kézirat szerzője.

Zoványi 1940-ben még nem tudott ilyen munkáról. A kéziratot halála előtt (†1958) három évvel leltározta a Ráday Levéltár, de úgy látszik, ő ezt nem látta. Vélhetően szemet szúrt volna neki, hogy a szerző mosoni prédikátor és ifjú volt 1671-ben, az pedig sem a samarjai apára, sem a komáromi esperesre nem illett. Életkoruk sem egyeztethető össze az alább következő teljes címmel. Száki Ferenc 1667 utáni sorsáról pedig nem tudott semmit. Így tudomása valaki említéséből vagy talán könyvjegyzékből származott. Ebből tévesen feltételezte a szerzöséget. Egyik emlegetett Száki Jánosnak sem volt ilyen munkája, Ferencnek sem. Nem is lehetett.

Így tehát sem idősb Száki János nem szerzett ilyen munkát 1671-ben, máskor sem. Csupán két köszöntő versét ismerjük. Fiait sem tekinthetjük szerzőnek. Ellenben ismerjük a valódi szerzőt, akinek adatait is fel kellene kutatnunk.

\section{Mi rejlik Zoványi emlitése mögött?}

Ha volt is valamilyen adata vagy gyanítása Zoványinak, ezt nem tisztázta kellően, nem is tisztázhatta. Tudniillik a kipontozott címü munka nem jelent meg nyomtatásban, sőt nem is kiadásra készült. Napjainkban a Ráday Könyvtárban található. ${ }^{34}$ Kézirattári jelzete K. 1. 172. Négy részre tagolta leírója:
1. Keresztelés
$3-11$.
2. Egyházkelés
$11-19$.
3. Urvacsora
$23-43$.
4. Esketés
$43-57$.

Eredeti terjedelme $[1]_{8}-[10]_{8}=[80]$ folio; ebböl hiányzik: ff. $[4]_{1+4}$ és $[8]_{1+4}$; tehát tíz nyolcleveles füzetből állott, összesen nyolcvan levélből vagy 160 lapból. Valamikor kiszakadt a negyedik és a nyolcadik füzet első levél-párja.

Mostani terjedelme a Száki-féle kéziratos szövegnek 57 lap, utólag, könyvtárilag számozva. Üres a 2, 20-22. lap. A 47. lap elött még lennie kellett két teleírt lapnak, ez elveszett. Eredeti számozást nem tartalmaz, de van őrszó (custos) végig. Bizonyos ebből és a 47. lap tetején olvasható hiányos mondatból, hogy

${ }^{34}$ A kézirat sorsa és korábbi tulajdonosa ismeretlen, csak 1955-ben leltározták. A szerzeményezés szintén tisztázatlan, nem maradt adat, amelyböl tudhatnánk, kitöl és mikor jutott hozzá a gyüjtemény. 
elveszett a kéziratból két lap. A kötetke mérete $155 \mathrm{~mm} \times 120 \mathrm{~mm}$, az írástüköré $135 \mathrm{~mm} \times 90 \mathrm{~mm}$, custossal együtt. A kézirat teljes címe elárulja a szerzőt is: ${ }^{35}$

Az Helvétiaj Valláson lévö Ecclésiának némely Egyházi Ceremóniájokrul és Rend tartásokrul való kis könyvecske, mely az Ágendából contraháltatott és egyéb Authorokból öszve szedegettetett. Mosoni iffiú Prédicátor Száki János által Anno 1671. die 11. Junij.

\section{Ki lehetett a mosoni prédikátor?}

Elmondhatjuk tehát, hogy eddig ismeretlen Száki volt a mosoni lelkész és a kéziratos liturgikus segédlet összeírója. Vajon az itt emlegetett többi Szákival egy családba vagy legalább rokonságba tartozott-e? Erre vonatkozott volna Zoványi sejtése vagy utalása? Ezt nem igazolhatjuk, de a családnév ritkasága miatt, ${ }^{36}$ illetve arra gondolva, hogy az elég kevés Száki néven ismert személy zömében Komárom megyéből származott, ezt elképzelhető, de jelenleg igazolatlan.

Ki lehetett akkor a legifjabb Száki János apja?

Száki Ferenc húsz évesen ment Németalföldre. Ekkor már nős és gyermekes férfiúnak kellett volna lennie? Tudniillik a legifjabb Száki Jánosnak az 1660-as évek közepén valahol (Pápán?) el kellett kezdenie felsőbb tanulmányait. Csak így történhetett, hogy fél évtizedes tanulás és legalább egy évi iskolai (rektori) szolgálat után 1671-ben Moson megválasztott prédikátoraként szolgáljon. Azaz 1650 táján kellett születnie, hisz nagyjából tizenöt évesen léptek felsőbb tanulmányokra akadémiai osztályba diákjaink. Születése táján Ferenc még nagykamasz volt. Képzelhető-e, hogy a protestánsok üldöztetése idején ő maga soha többé nem, de fia hazajön Németországból prédikátornak?

Idősb Száki János lehetett a nagyapa, hisz püspök létére sem lehetett két János nevü fia.

Akkor a legifjabb János apja lehetett a komjáti esperes. Azért, mert bizonnyal idősebb volt legalább néhány évvel, mint Ferenc öccse. Aligha volt olyan javakorabeli esperes, aki ne lett volna családos ember megválasztása idején. A latolgat-

${ }^{35}$ Itt nem betű szerinti hűséggel, hanem átírásban, mai helyesírásunkhoz közelítve és egységesítve idézem a címet. - A kézirat kutatástörténete csupán annyi, hogy nyomtatásban megjelent róla Zoványi lexikona előtt egy említés. Vö. BENEDEK Sándor, A magyarországi református egyház istentiszteletének múltja, [Sokszorosítás], kiad. Teleky Béla, Örisziget, 1971, 43-44. Benedek summás ítélete ennyi: „Ezekben egyszerúen lemásolta Samarjai János agendájának azonos szertartásait, mégis azzal a különbséggel, hogy nem vette át a Samarjai agendájában található egy kérdést, hanem helyette fölvette Melotai [ilyen alakban használja] agendájának három kérdését". - A filológiai vizsgálat ezt sokkal árnyaltabbnak, és az idézett következtetést tarthatatlannak mutatja. - Az úrvacsorai kérdések történetéről, az itt említettet is idézve, Valóban hiszen-é címü tanulmányom jelenik meg a Theológiai Szemle 2016-os évfolyamában.

${ }^{36}$ KÁzmér Miklós, Régi magyar családnevek szótára, XIV-XVIII. század, Budapest, Magyar Nyelvtudományi Társaság, 1993. 
ható lehetőségek közül ez róla is valószínü. De az sem lehetetlen, hogy téves ez az elképzelés. Jelenleg egyiket sincs mivel bizonyítanunk.

Adódik egy további bizonytalanság, de ez is tartozhat az ároni családfához. Lehet, hogy a legifjabb Száki János leszármazottja az egyik Pápai rektor? Azt a legújabb áttekintés is csupán esetlegesen véli, hogy a Szenci Száki ároni család leszármazottja. Ö az 1698-ban beiratkozott Szenci [Száki?] Ferenc, aki aztán Tany rektora volt három évvel később. ${ }^{37}$ Mosonból való elüzetése után nem tudjuk, hol húzta meg magát a legifjabb Szenci Száki János, és meddig élt. Megnősülhetett húszas éveiben, életkorába beleillik, hogy a század végén tizenöt év körüli fia Pápán diákoskodjék. Nem tudhatjuk. Azt sem, hogy a gyéren ismert 18. századi Száki nevüek közül volt-e még valaki, aki a családfát folytatta.

Hogyha mégis az igazolódna később fellelt dokumentumokból, hogy a név azonossága nem jelent vérrokonságot, akkor is lehetett döntő hatása a kézirat összeírójára csupán az övével egyező családnév. Az ifjú prédikátor a Dunántúlnak a Huszár Gál idejétől erős református gyülekezetében mindenképpen tudott a komjáti esperes vértanúságáról és püspök atyjáról. Hisz őt magát is ugyanaz a történelmi helyzet fenyegette. Sújtotta is. Kézirata befejezése után néhány hónappal Moson református templomát is eröszakkal foglalták el, és a környék prédikátoraival együtt a legifjabb Száki Jánost is elüldözte az egri püspök.

\section{FEKETE, CSABA}

\section{The Száki Family}

Nearly all the available records are collected here concerning the Szenci Száky family, together with some additions and due corrections, as there are inadequacies and misinterpretations dispersed in traditional articles, even in up to date desk books.

János Szenci Száki, senior (about 1600-1675), acted as superintendens to the reformed at the North-Danube era and church district between 1656 and 1675. No data are known of his home schooling and perhaps abroad theological education. He was also put on trial in the so called 'Mourning Decade' of protestant ministers and teachers, 1671-1681, and sentenced. By that time his son became one of the first martyrs of the protestants, chased by the ruling roman catholic bishops. In consequence, the reverend Száki resigned his post, and in the next year died.

János Szenci Száki, junior (about 1630-1672), dean and reformed minister of the same district, because of his reformed faith and confession was tortured as heretics and burnt at stake 1st of September, 1672, Komárom (now Komarno, Slovakia). His fate is recorded in books and recollections of his age, other detailes of his life and education not.

Ferenc Szenci Száki (about 1640-after 1694) reformed minister, younger son of the above superintendent, having absolved home studies, went to the Netherlands in 1655, where he spent nearly 12 years. There he published a whole series of dissertations, and had a doctor degree in theology. In the meantime allso spent years in Great Britain. Then he became settled in Kassel,

${ }^{37}$ KöBlös, Kránttz 2009, i. m. 738. 
Germany. So far no modern study have cleared up the end of his life, and nobody had summed up all of his works and activities.

Perhaps offspring of the same family, son of János Szenci Száki junior, was a young reformed minister of the same name, acting in town Moson, at the Danube, near to Vienna. In the year 1671 he had outlined a manuscript liturgy, named 'Agenda', as a young pastor, which fortunately survived. Hungarian full title of the unpublished small booklet, and a short content is quoted here. The next year the local church of the reformed became confiscated by military power, and the young minister, author of the liturgical manuscript, expelled. No other details are known at the moment of his later life and carrier.

Keywords: Church history, Hungarian reformed church, Mournful decade of Hungarian protestants (1671-1681), Martyrs of Hungarian protestants, 17th century protestant liturgy, Száki (Szenci Száki) family 